COSTA E; SOUZA TG; BENTEO GL; BENETT KSS; BENETT CGS. 2013. Okra seedlings production in protected environment, testing substrates and producing fruits in field. Horticultura Brasileira 31: 8-14.

\title{
Okra seedlings production in protected environment, testing substrates and producing fruits in field
}

\author{
Edilson Costa ${ }^{1}$; Taynara G de Souza ${ }^{2}$; Gleciane de L Benteo ${ }^{2}$; Katiane SS Benett ${ }^{3}$; Cleiton GS Benett $^{3}$ \\ ${ }^{1}$ UEMS, Rod. MS 30 km 6,5, Zona rural, 79540-000 Cassilândia-MS; mestrine@uems.br; ${ }^{2}$ UEMS, Rod. Aquidauana-UEMS km 12, \\ 79200-000 Aquidauana-MS; gon_tay@hotmail.com; gleicianebenteo@hotmail.com; ${ }^{3}$ UEG, Rod. GO-330 km 241, Anel Viário s/n, \\ 75780-000 Ipameri-GO; kasantiago@ig.com.br; cbenett@hotmail.com
}

\begin{abstract}
The okra grows well in hot weather, finding favorable conditions for development in Brazil. We evaluated the production of okra seedlings and productivity. The experiment was conducted in the experimental area of the State University of Mato Grosso do Sul, in Aquidauana. In the seedling phase we tested substrates $(100 \%$ triturated cassava stems, $75 \%$ triturated cassava stems and $25 \%$ vermiculite, $50 \%$ triturated cassava stems and $50 \%$ vermiculite, $25 \%$ triturated cassava stems and $75 \%$ vermiculite and $100 \%$ vermiculite). These substrates were placed in two protected environments (nursery with black screen, $50 \%$ of shading, and aluminized screen, $50 \%$ of shading). Each environment was considered an experiment conducted in completely randomized design with eight replications. After that we realized joint analysis. In the field, a total of 10 treatments generated from combinations of environments and substrates ( 2 environments $\mathrm{x}$ 5 substrates) were distributed in a randomized block design with four replications. The average proportions of cassava stems and vermiculite may be suitable for okra seedlings. The results of shoot and total dry phytomass indicate that the aluminized screen can be recommended for okra seedlings production when the substrate with a $1: 1$ ratio is used. Seedlings grown on higher percentages of vermiculite anticipate production, while seedlings produced only in cassava stems tend to slow it down. The aluminized screen tends to increase the yield of okra seedlings. Average proportions of vermiculite and cassava stems for seedling production under aluminized screen, provide more fruits and yield of okra in Aquidauana.
\end{abstract}

Keywords: Abelmoschus esculentus, cassava stems, vermiculite, nursery farm.

\section{RESUMO}

Formação de mudas de quiabeiro sob ambientes protegidos, em diferentes substratos, e produção de frutos a campo

O quiabeiro é hortaliça de clima quente, encontrando condições favoráveis de desenvolvimento no Brasil. O presente trabalho teve como objetivo avaliar a produção de mudas e a produtividade de quiabeiro. $\mathrm{O}$ experimento foi conduzido na área experimental da Universidade Estadual de Mato Grosso do Sul em Aquidauana. $\mathrm{Na}$ fase de mudas, foram testados substratos $(100 \%$ ramas de mandioca triturada; $75 \%$ ramas de mandioca triturada $+25 \%$ de vermiculita; $50 \%$ ramas de mandioca triturada $+50 \%$ de vermiculita; $25 \%$ ramas de mandioca triturada $+75 \%$ vermiculita e $100 \%$ vermiculita). Estes substratos foram dispostos em dois ambientes protegidos (viveiro agrícola de tela de monofilamento de $50 \%$ de sombreamento e viveiro agrícola de tela aluminizada de $50 \%$ de sombreamento). Cada ambiente foi considerado um experimento, conduzido no delineamento inteiramente casualizado, com oito repetições. Em seguida, realizou-se a análise conjunta. No campo, foram distribuídos os 10 tratamentos gerados a partir das combinações entre ambientes e substratos ( 2 ambientes x 5 substratos), no delineamento blocos casualizados, com quatro repetições. As proporções médias de ramas de mandioca e vermiculita podem ser indicadas para a formação de mudas de quiabeiro. Pelas fitomassas seca aérea e total o ambiente com tela aluminizada pode ser indicado para produção de mudas de quiabeiro com a utilização do substrato na proporção 1:1. Mudas provenientes de maiores porcentagens de vermiculita antecipam a produção, enquanto que mudas oriundas apenas de ramas tendem a retardar essa fase. Mudas oriundas do ambiente aluminizado tendem a incrementar a produção de frutos de quiabeiro. Proporções médias de vermiculita e ramas, para mudas produzidas na tela aluminizada, propiciam maior número de frutos e produtividade do quiabeiro em Aquidauana.

Palavras-chave: Abelmoschus esculentus, ramas de mandioca, vermiculita, viveiro agrícola.

(Recebido para publicação em 26 de janeiro de 2012; aceito em 31 de outubro de 2012)

(Received on January 26, 2012; accepted on October 31, 2012)

$\mathrm{O}$ kra production (Abelmoschus esculentus) is of great national importance for representing an interesting alternative source of income for family agriculture, mainly because of its early production and because of its relatively long period of harvest, besides the possibility of being cultivated during all year long in regions of low heights (Guedes et al., 2006). The okra is a vegetable of hot weather and needs temperatures between 21 and $35^{\circ} \mathrm{C}$ for germination and good development (Mota et al., 2006); thus, okra finds favorable conditions in Aquidauana, Mato Grosso do Sul State, Brazil.

Popularly grown in the northeast and southeast of Brazil during the whole 
year, okra can be considered as a major source of income for small farmers in those regions (Castro et al., 2004). Its production is directed to the domestic market, because okra produced in Brazil looks plump, not being appreciated by the overseas market, which demands quinate fruits (Purquerio et al., 2005).

Modolo et al. (2001) emphasize that in conventional cultivation the sowing of okra is usually done directly in the soil, four seeds/pit. This method provokes a great seed waste per hectare, because the seeds show dormancy through the impermeability of the integument, which makes the germination difficult. Thus, the production of individual seedlings, using cell trays, is an advantageous option, mainly because the okra plant shows some difficulty in the initial culture.

In seedling production, the inputs used in the substrate are important to obtain plants with high quality and high adaptability to the environment (Silveira et al., 2002). The substrate may allow that the seedling develop with stability, aiding the structure of the root system; should be easy to acquire and transport, free of pathogens, rich in essential nutrients, with suitable $\mathrm{pH}$, good texture and structure. For materials with organic matter, $\mathrm{pH}$ between 5.0 and 5.8 is recommended, ensuring satisfactory availability of macro and micronutrients to plants (Kämpf, 2000).

The cultivation environment is another factor that may influence directly in the quality of seedlings. For this purpose, the use of polypropylene screen (monofilament or raffia) is becoming popular. The reduction of the incidence of sunlight, according to Queiroga et al. (2001), provides greater dry mass production to the plants. Another kind of screen used is the thermo-reflective, color aluminized, which also interacts in plant responses in the protected environment.

In literature, several researches about high quality vegetable seedlings were found; however, studies about their productive capacity are scarce. For okra, work involving stages of seedling production and the production in the field were developed by Modolo \& Tessarioli Neto (1999) and Modolo et al. (2001).
In the seedling stage, the researchers observed higher development of okra plant in trays with larger cell volume and in the field these plants produced greater amount of fruits. Lower seedling development in substrate containing rice hulls was observed, and in the field these plants produced lower amount of mass and smaller amount of fruits, regardless of the cell volume.

This work aimed to evaluate the production of the okra seedling with substrates formulated by triturated cassava stems and vermiculite in two protected environments, and the productivity in the field.

\section{MATERIAL AND METHODS}

The experiments for seedling production and okra fruit production, cultivar Santa Cruz- 47, were carried out from May to October 2010, in Aquidauana, Mato Grosso do Sul $\left(20^{\circ} 27^{\prime} \mathrm{S}, 55^{\circ} 40^{\prime} \mathrm{W}\right.$, altitude $\left.174 \mathrm{~m}\right)$, interface area between Cerrado and Pantanal. The weather of the county, according to Köppen classification, is Aw mesothermal, defined as humid tropical climate, with mean annual temperature of $29^{\circ} \mathrm{C}$.

Seedling production - The seedling production stage was carried out in two protected environments: $\mathrm{A} 1=$ nursery covered with monofilament shade screen, $50 \%$ of shading, and $\mathrm{A} 2=$ nursery covered with aluminized shade screen, $50 \%$ of shading. In each of them, five substrates obtained from the mixture of vermiculite and triturated cassava stems were evaluated: $\mathrm{S} 1=$ $100 \%$ of triturated cassava stems; $\mathrm{S} 2=$ $75 \%$ of triturated cassava stems and $25 \%$ of vermiculite; $\mathrm{S} 3=50 \%$ of triturated cassava stems and $50 \%$ of vermiculite; $\mathrm{S} 4=25 \%$ of triturated cassava stems and $75 \%$ of vermiculite and S5 $=100 \%$ of vermiculite. In each environment, the experiment was carried out in a completely randomized design, with eight replications of two plants.

The choice of these materials for the composition of substrates is guided in the physical properties of vermiculite, described in several scientific studies, as well as in cassava stems which are agricultural residues abundant in the region of Aquidauana.

The grain size of the triturated stems was determined using sieves 5 , 10, 16, 30, 50, 100 and Background $\left(\mathrm{n}^{\mathrm{o}}, \mathrm{ABNT}\right)$. The percentage of the particles of the triturated cassava stems, retained in these sieves with holes of $4.0 ; 2.0 ; 1.2 ; 0.6 ; 0.3 ; 0.15$ and $0.0 \mathrm{~mm}$ diameter, were respectively: $2.82 ; 50.85$; $15.45 ; 19.87 ; 7.52 ; 2.47$ and $1.03 \%$. The geometric mean diameter (DMG) of the particles was $1.93 \mathrm{~mm}$ and the fineness modulus (MF) was 3.99. A total of $86.17 \%$ of the particles had diameter between 0.6 and $2.0 \mathrm{~mm}$. The densities of this material were determined; the wet density was $833.33 \mathrm{~kg} \mathrm{~m}^{-3}$ and the dry density $167.19 \mathrm{~kg} \mathrm{~m}^{-3}$.

The cassava stems were triturated in a hammer mill (TRAPP brand, model TRF 650), using a sieve of $8 \mathrm{~mm}$, dried under the sun. The chemical analysis of the stems indicated: $\mathrm{pH}\left(\mathrm{CaCl}_{2}\right)=8.7$; organic $\mathrm{C} ; \mathrm{N}, \mathrm{C} / \mathrm{N}, \mathrm{P}, \mathrm{K}, \mathrm{Ca}, \mathrm{Mg}$ and $\mathrm{Na}(\%)$ ratio, respectively, of: 43.15 ; $0.97 ; 44.50 ; 0.24 ; 1.44 ; 1.24 ; 0.32$ and 0.02. Copper, iron, manganese and zinc $\left(\mathrm{mg} \mathrm{kg}^{-1}\right)$, respectively, of: $7.83 ; 222.73$; 103.09 and 41.85 .

The seedlings were grown in polystyrene trays of 128 cells. The substrates were fertilized, using $2.5 \mathrm{~kg}$ $\mathrm{m}^{-3}$ superphosphate, $0.3 \mathrm{~kg} \mathrm{~m}^{-3}$ potassium chloride and $1.5 \mathrm{~kg} \mathrm{~m}^{-3}$ limestone (filler type). Foliar fertilization was performed at 20 days after sowing (DAS) with 1008-08 (NPK) at a dose of $20 \mathrm{~mL}$ to 20 liters of water.

The emergence speed index (IVE), the percentage of emergence (PE), the mean emergence time (TME) and the average speed of emergence (VME) were evaluated. At 31 days after sowing plant height, stem base diameter and dry mass of aboveground part and root were evaluated. The height/stem base diameter ratios (RAD), aboveground part/root dry phytomass (RMS), and Dickson quality index (IQD), where $\mathrm{IQD}=[\mathrm{MST} /(\mathrm{RAD}+\mathrm{RMS})]$ and $\mathrm{MST}=$ plant total dry mass, were determined.

The data were submitted to individual analysis of variance of the substrates, for each cultivation environment, then carrying out the evaluation of the mean squares of the residues (Banzatto \& 
Kronka, 2006) and the joint analysis of environments. For this study, the statistical program SISVAR 5.3 was used, and the averages were compared using $\mathrm{F}<0.05$ probability.

Fruit production - The treatments in the field were derived from the combination between environments and substrates ( 2 environments x 5 substrates), arranged in a randomized block design, with four replications. The plots consisted of 15 plants, consisting of three rows with five plants each, with plot spaced at $0.6 \times 0.5 \mathrm{~m}$.

The soil of the experimental area for the establishment of okra seedlings was classified as Dystrophic Ultisol to moderate, sandy-clay texture. The soil chemical properties were determined before the establishment of the experiment, with the following attributes observed in the 0.0 to $0.20 \mathrm{~m}$ layer: $\mathrm{pH}\left(\mathrm{H}_{2} \mathrm{O}\right)=6.1$; organic matter $=3.3 \% ; \mathrm{P}=56.6 \mathrm{mg} \mathrm{dm}^{-3} \mathrm{~K}, \mathrm{Ca}, \mathrm{Mg}$ and $\mathrm{H}+\mathrm{Al}=0.48 ; 5.4 ; 2.3$ and $3.3 \mathrm{cmol}_{\mathrm{c}}$ $\mathrm{dm}^{-3}$, respectively. The soil was prepared by harrowing and then the pits were opened. The seedling transplantation occurred 31 days after sowing (DAS), two seedlings being placed in each pit and, after 25 days, the thinning was performed leaving only one plant per pit.

The weed control was performed manually and the other cultural and phytosanitary practices were the usually recommended for the crop. The irrigation was carried out through spraying, according to the necessities of the plants. A single dose of nitrogen was applied after 20 days of emergence, around each pit. The top dressing was performed after 30 days of transplanting, using the formulation NPK 05-20-20, 20 $\mathrm{g}$ for each plant.

The fruits were harvested with 8-9 cm twice a week, for 90 days, considering the first harvest 52 days after transplant. The number and the total mass of the fruits were evaluated.

The data were submitted to the analysis of variance and the average was compared by $\mathrm{F}$ test at $5 \%$ probability, using the statistical program SISVAR 5.3 .

\section{RESULTS AND DISCUSSION}

Seedling production - For all traits evaluated, the ratio among the mean squares of the residue (RQMR) of the individual analysis of variance of the experiments did not exceed 7:1, allowing, therefore, the performance of joint analysis of the experiments (Banzatto \& Kronka, 2006) and the comparison of the protected environments.

Only the percentage of emergence
(PE) and aboveground part/root dry biomass ratio (RMS) did not show significant difference for the interaction among environments and substrates. The significant interaction for the other traits analyzed shows the existence of a combination between environment and substrate promoting a better development of okra seedlings.

The lower rate of seedling emergence speed index in the substrate with higher percentage of stems (Table 1), where seedlings had greater difficulty in issuing hypocotyl and primary root, as well as the epicotyl, is associated to the granulometric traits of the stem (DGM= $1.93 \mathrm{~mm}$ ), which allowed less seed-moist substrate contact. The percentage of okra seedling emergence was higher than the ones found by Lopes (2007), in which the higher percentage of emergence was $79.8 \%$. In lettuce seedlings, Oliveira et al. (2008) obtained higher percentage of seedlings in vermiculite $(75.55 \%)$. The rapid and uniform germination of seeds, followed by immediate seedling emergence are desirable characteristics for crop species, showing its vigor under environmental conditions (Santos et al., 2009), traits observed in this work.

For the percentages of 50,75 and $100 \%$ of stems, the aluminized screen provided higher average speed

Table 1. Interactions between environments and substrates obtained from okra seeds grown under protected environment (interações entre ambientes e substratos obtidos de sementes de quiabo cultivadas sob ambiente protegido). Aquidauana, UEMS, 2010.

\begin{tabular}{lccccc}
\hline \multirow{2}{*}{ Cassava stem/vermiculite } & \multicolumn{2}{c}{ Emergence velocity index } & & \multicolumn{2}{c}{ Emergence (\%) } \\
\cline { 2 - 3 } \cline { 5 - 6 } & Black shade screen & Aluminized screen & & Black shade screen & Aluminized screen \\
\hline $100 \% \mathrm{RM}+0 \% \mathrm{VE}$ & $5.73 \mathrm{Bb}^{*}$ & $7.13 \mathrm{Ba}$ & & $86.61 \mathrm{Aa}$ & $85.16 \mathrm{Ba}$ \\
$75 \% \mathrm{RM}+25 \% \mathrm{VE}$ & $8.02 \mathrm{Aa}$ & $8.57 \mathrm{ABa}$ & & $96.88 \mathrm{Aa}$ & $92.19 \mathrm{Aba}$ \\
$50 \% \mathrm{RM}+50 \% \mathrm{VE}$ & $6.40 \mathrm{ABb}$ & $9.20 \mathrm{Aa}$ & & $96.10 \mathrm{Aa}$ & $96.88 \mathrm{Aba}$ \\
$25 \% \mathrm{RM}+75 \% \mathrm{VE}$ & $7.92 \mathrm{Ab}$ & $9.28 \mathrm{Aa}$ & & $98.44 \mathrm{Aa}$ & $100.00 \mathrm{Aa}$ \\
$0 \% \mathrm{RM}+100 \% \mathrm{VE}$ & $7.29 \mathrm{Aba}$ & $7.22 \mathrm{Ba}$ & & $100.00 \mathrm{Aa}$ & $99.22 \mathrm{Aba}$ \\
\hline & \multicolumn{2}{c}{ Emergence average time (days) } & & Emergence average velocity (days $\left.{ }^{-1}\right)$ \\
\hline $100 \% \mathrm{RM}+0 \% \mathrm{VE}$ & $12.30 \mathrm{Aa}$ & $11.94 \mathrm{Bb}$ & & $0.081 \mathrm{Ab}$ & $0.084 \mathrm{Aa}$ \\
$75 \% \mathrm{RM}+25 \% \mathrm{VE}$ & $12.20 \mathrm{Aa}$ & $11.98 \mathrm{ABb}$ & & $0.082 \mathrm{Ab}$ & $0.083 \mathrm{Aba}$ \\
$50 \% \mathrm{RM}+50 \% \mathrm{VE}$ & $12.25 \mathrm{Aa}$ & $11.99 \mathrm{ABb}$ & & $0.082 \mathrm{Ab}$ & $0.083 \mathrm{Aba}$ \\
$25 \% \mathrm{RM}+75 \% \mathrm{VE}$ & $12.19 \mathrm{Aa}$ & $12.07 \mathrm{ABa}$ & & $0.082 \mathrm{Aa}$ & $0.083 \mathrm{Aba}$ \\
$0 \% \mathrm{RM}+100 \% \mathrm{VE}$ & $12.11 \mathrm{Aa}$ & $12.15 \mathrm{Aa}$ & & $0.083 \mathrm{Aa}$ & $0.082 \mathrm{Ba}$ \\
\hline
\end{tabular}

$\mathrm{RM}=$ cassava stem (rama de mandioca); $\mathrm{VE}=$ vermiculite (vermiculita); *Same uppercase letters in the columns and lowercase letters in the rows do not differ by Tukey test, $5 \%$ (letras iguais maiúsculas nas colunas e minúsculas nas linhas não diferem entre si pelo Teste de Tukey, 5\%). 
Table 2. Interactions between environments and substrates obtained from okra seedlings grown under protected environment (interações entre ambientes e substratos obtidos de plântulas de quiabo cultivadas sob ambiente protegido). Aquidauana, UEMS, 2010.

\begin{tabular}{lccccc}
\hline \multirow{2}{*}{ Cassava stem/vermiculite } & \multicolumn{2}{c}{ Plant height (cm) } & & \multicolumn{2}{c}{ Stem diameter (mm) } \\
\cline { 2 - 3 } \cline { 5 - 6 } & Black shade screen & Aluminized screen & & Black shade screen & Aluminized screen \\
\hline $100 \% \mathrm{RM}+0 \% \mathrm{VE}$ & $6.42 \mathrm{Ca}^{*}$ & $5.28 \mathrm{Cb}$ & & $2.12 \mathrm{Bb}$ & $2.38 \mathrm{Aa}$ \\
$75 \% \mathrm{RM}+25 \% \mathrm{VE}$ & $8.38 \mathrm{Aa}$ & $6.24 \mathrm{Ab}$ & & $2.33 \mathrm{ABa}$ & $2.34 \mathrm{Aa}$ \\
$50 \% \mathrm{RM}+50 \% \mathrm{VE}$ & $7.73 \mathrm{ABa}$ & $5.98 \mathrm{ABb}$ & & $2.36 \mathrm{ABa}$ & $2.33 \mathrm{Aa}$ \\
$25 \% \mathrm{RM}+75 \% \mathrm{VE}$ & $7.57 \mathrm{Ba}$ & $5.59 \mathrm{BCb}$ & & $2.41 \mathrm{Aa}$ & $2.38 \mathrm{Aa}$ \\
$0 \% \mathrm{RM}+100 \% \mathrm{VE}$ & $6.54 \mathrm{Ca}$ & $6.13 \mathrm{Ab}$ & & $2.30 \mathrm{ABa}$ & $2.21 \mathrm{Aa}$ \\
\hline & Aerial and root dry phytomass relation & & Height and stem diameter ratio \\
\hline $100 \% \mathrm{RM}+0 \% \mathrm{VE}$ & $3.98 \mathrm{Aa}$ & $4.25 \mathrm{Aa}$ & & $3.03 \mathrm{BCa}$ & $2.23 \mathrm{Cb}$ \\
$75 \% \mathrm{RM}+25 \% \mathrm{VE}$ & $3.85 \mathrm{Ab}$ & $4.86 \mathrm{Aa}$ & & $3.46 \mathrm{Aa}$ & $2.69 \mathrm{ABb}$ \\
$50 \% \mathrm{RM}+50 \% \mathrm{VE}$ & $4.06 \mathrm{Aa}$ & $4.63 \mathrm{Aa}$ & & $3.28 \mathrm{ABa}$ & $2.58 \mathrm{BCb}$ \\
$25 \% \mathrm{RM}+75 \% \mathrm{VE}$ & $4.21 \mathrm{Aa}$ & $4.80 \mathrm{Aa}$ & & $3.14 \mathrm{ABCa}$ & $2.36 \mathrm{BCb}$ \\
$0 \% \mathrm{RM}+100 \% \mathrm{VE}$ & $3.64 \mathrm{Ab}$ & $4.65 \mathrm{Aa}$ & & $2.85 \mathrm{Ca}$ & $2.80 \mathrm{Aa}$ \\
\hline & $\mathrm{Aerial}$ dry phytomass $\mathbf{g})$ & & Root system dry phytomass $\mathbf{( g )}$ \\
\hline $100 \% \mathrm{RM}+0 \% \mathrm{VE}$ & $0.081 \mathrm{ABa}$ & $0.083 \mathrm{Ba}$ & & $0.021 \mathrm{Aa}$ & $0.019 \mathrm{Aba}$ \\
$75 \% \mathrm{RM}+25 \% \mathrm{VE}$ & $0.087 \mathrm{Aa}$ & $0.084 \mathrm{Ba}$ & & $0.023 \mathrm{Aa}$ & $0.018 \mathrm{ABb}$ \\
$50 \% \mathrm{RM}+50 \% \mathrm{VE}$ & $0.087 \mathrm{Ab}$ & $0.099 \mathrm{Aa}$ & & $0.022 \mathrm{Aa}$ & $0.022 \mathrm{Aa}$ \\
$25 \% \mathrm{RM}+75 \% \mathrm{VE}$ & $0.081 \mathrm{ABa}$ & $0.080 \mathrm{BCa}$ & & $0.019 \mathrm{Aa}$ & $0.017 \mathrm{Ba}$ \\
$0 \% \mathrm{RM}+100 \% \mathrm{VE}$ & $0.066 \mathrm{Ba}$ & $0.066 \mathrm{Ca}$ & & $0.018 \mathrm{Aa}$ & $0.016 \mathrm{Ba}$ \\
\hline & \multicolumn{2}{c}{ Total dry phytomass (g) } & & Dickson quality index \\
\hline $100 \% \mathrm{RM}+0 \% \mathrm{VE}$ & $0.101 \mathrm{Aa}$ & $0.102 \mathrm{Ba}$ & & $0.015 \mathrm{Aa}$ & 0.016 \\
$75 \% \mathrm{RM}+25 \% \mathrm{VE}$ & $0.109 \mathrm{Aa}$ & $0.102 \mathrm{Ba}$ & & $0.015 \mathrm{Aa}$ & $0.014 \mathrm{BCa}$ \\
$50 \% \mathrm{RM}+50 \% \mathrm{VE}$ & $0.109 \mathrm{Ab}$ & $0.122 \mathrm{Aa}$ & & $0.015 \mathrm{Aa}$ & $0.017 \mathrm{Aa}$ \\
$25 \% \mathrm{RM}+75 \% \mathrm{VE}$ & $0.100 \mathrm{ABa}$ & $0.097 \mathrm{BCa}$ & & $0.014 \mathrm{Aa}$ & $0.014 \mathrm{BCa}$ \\
$0 \% \mathrm{RM}+100 \% \mathrm{VE}$ & $0.084 \mathrm{Ba}$ & $0.081 \mathrm{Ca}$ & & $0.013 \mathrm{Aa}$ & $0.012 \mathrm{Ca}$ \\
\hline
\end{tabular}

$\mathrm{RM}=$ cassava stem (rama de mandioca); $\mathrm{VE}=$ vermiculite (vermiculita); ${ }^{*}$ Same uppercase letters in the columns and lowercase letters in the rows do not differ by Tukey test, $5 \%$ (letras iguais maiúsculas nas colunas e minúsculas nas linhas não diferem entre si pelo Teste de Tukey, 5\%).

emergence than the monofilament screen (Table 1). The greater reflection of sunlight in the nursery with aluminized screen, which decreases the temperature in the summer, keeps the temperature in the winter and maintains high relative humidity during the day (Guiselini \& Sentelhas, 2004), gave better internal conditions for the seeds of these substrates, allowing the acceleration of emergence.

The height of the seedlings in two protected environments, the stem base diameter in monofilament screen, and the shoot and total dry phytomass and IQD in aluminized screen were more expressive in substrates containing mixtures of materials than in substrates with only one material. This corroborates with Liz \& Carrijo (2008) who reported that the mixture of materials for the constitution of substrate improves the physical characteristics of the environment and provides better seedling development.

The height/stem base diameter ratio expresses the balance of seedling growth, involving two characteristics in an index (Cruz et al., 2006). The lower ratio was obtained using the substrates $0 \% \mathrm{RM}+100 \% \mathrm{VE}$ (2.85) in monofilament screen and $100 \% \mathrm{RM}+0 \% \mathrm{VE}(2.23)$ in aluminized screen (Table 2). This indicates that the increase of the seedling height was followed by the increase of the thickness of the stem base, which did not characterize etiolation, in all the environments and substrates.

According to Cruz et al. (2006), aboveground part/root dry phytomass ratio expresses the seedling quality. In aluminized screen, using the substrate
$75 \% \mathrm{RM}+25 \% \mathrm{VE}$, a higher aboveground part/root dry phytomass ratio (4.86) of the seedlings was obtained, despite not differing from the other substrates (Table 2). As etiolation was not detected and because of a good distribution among aboveground part and root dry phytomass, it can be stated that the seedlings showed satisfactory quality and vigor.

In the evaluation of the substrates in each environment, for the stem base diameter was observed that the seedlings of the substrate $100 \% \mathrm{RM}+0 \% \mathrm{VE}$ in monofilament screen obtained lower value (Table 2). The fact that the substrate $100 \% \mathrm{RM}+0 \% \mathrm{VE}$ did not show good performance for stem diameter, certainly, is related to the nutritional resources of this substrate, associated with high carbon/nitrogen 
Table 3. Yield data obtained from okra plants originated from seedlings grown in different substrates and environments (dados de produção do quiabeiro originado de plântulas crescidas em diversos substratos e ambientes). Aquidauana, UEMS, 2010.

\begin{tabular}{lccccc}
\hline \multicolumn{5}{c}{ Fruits/plot $\left(\mathbf{n}^{\mathbf{0}}\right)$} \\
\hline S1 & S2 & S3 & S4 & S5 \\
\hline Black shade screen & $163.0 \mathrm{a}^{1}$ & $178.0 \mathrm{a}$ & $173.8 \mathrm{~b}$ & $184.3 \mathrm{a}$ & $203.5 \mathrm{a}$ \\
Aluminized screen & $193.3 \mathrm{a}$ & $196.3 \mathrm{a}$ & $223.8 \mathrm{a}$ & $204.8 \mathrm{a}$ & $193.3 \mathrm{a}$ \\
\hline F test & $1.23 \mathrm{~ns}$ & $0.17 \mathrm{~ns}$ & $21.04 *$ & $0.30 \mathrm{~ns}$ & $0.42 \mathrm{~ns}$ \\
CV(\%) & 21.7 & 33.6 & 7.8 & 27.4 & 11.3 \\
\hline \multicolumn{7}{c}{ Production (g/plot) } \\
\hline Black shade screen & $2257.7 \mathrm{a}$ & $2540.7 \mathrm{a}$ & $2409.7 \mathrm{~b}$ & $2610.1 \mathrm{a}$ & $2751.4 \mathrm{a}$ \\
Aluminized screen & $2737.4 \mathrm{a}$ & $2733.1 \mathrm{a}$ & $3138.5 \mathrm{a}$ & $2969.7 \mathrm{a}$ & $2710.1 \mathrm{a}$ \\
\hline F test & $0.76 \mathrm{~ns}$ & $0.25 \mathrm{~ns}$ & $13.02^{*}$ & $0.38 \mathrm{~ns}$ & $0.03 \mathrm{~ns}$ \\
CV(\%) & 31.1 & 46.6 & 10.3 & 29.5 & 12.9 \\
\hline & $2.60 \mathrm{a}$ & $2.92 \mathrm{a}$ & $2.77 \mathrm{~b}$ & $3.00 \mathrm{a}$ & $3.16 \mathrm{a}$ \\
\hline Black shade screen & $3.15 \mathrm{a}$ & $3.14 \mathrm{a}$ & $3.61 \mathrm{a}$ & $3.41 \mathrm{a}$ & $3.12 \mathrm{a}$ \\
Aluminized screen & $0.77 \mathrm{~ns}$ & $0.05 \mathrm{~ns}$ & $12.98^{*}$ & $1.48 \mathrm{~ns}$ & $0.02 \mathrm{~ns}$ \\
\hline F test & 31.1 & 46.7 & 10.3 & 25.07 & 13.0 \\
CV $(\%)$ & Yield (t/ha) &
\end{tabular}

${ }^{1}$ Same lowercase letters in the columns for each parameter do not differ by $\mathrm{F}$ test at $5 \%$ probability; ns= not significant; * significant; S1= $100 \%$ cassava stems; $\mathrm{S} 2=75 \%$ cassava stems $+25 \%$ vermiculite; $\mathrm{S} 3=50 \%$ cassava stems $+50 \%$ vermiculite; $\mathrm{S} 4=25 \%$ cassava stems + $75 \%$ vermiculite; S5 $=100 \%$ vermiculite; $\mathrm{CV}=$ coefficient of variation (letras iguais minúsculas nas colunas para cada característica não diferem entre si pelo teste $\mathrm{F}$ a $5 \%$ de probabilidade; $\mathrm{ns}=$ não significativo; * significativo; $\mathrm{S} 1=100 \%$ ramas de mandioca; $\mathrm{S} 2=75 \%$ ramas de mandioca $+25 \%$ vermiculita; $\mathrm{S} 3=50 \%$ ramas de mandioca $+50 \%$ vermiculita; $\mathrm{S} 4=25 \%$ ramas de mandioca $+75 \%$ vermiculita; $\mathrm{S} 5$ $100 \%$ vermiculita; $\mathrm{CV}=$ coeficiente de variação).

ratio of 43.15 and $\mathrm{pH}$ 8.7. Seedlings with small stem base diameter show difficulties in remaining upright after planting, and the damping-off due to this characteristic can result in death or deformation that may affect the production of the plant.

The seedlings grown in nursery with monofilament screen obtained higher heights, ranging from 6.42 $\mathrm{cm}(100 \% \mathrm{RM}+0 \% \mathrm{VE})$ to $8.38 \mathrm{~cm}$ $(75 \% \mathrm{RM}+25 \% \mathrm{VE})$, when compared to the aluminized screen (Table 2), showing that okra seedlings adapt better to the growth in this environment. This can be explained by the fact that because it is an environment that consisted of black shading screen, with higher retention of heat and more appropriate temperatures for the initial growth of okra seedlings. These conditions may have provided the substrate better water content traits for the seedling development, according to Costa et al. (2010) and Rodrigues et al. (2010), who observed good cucumber and tomato seedling growth, respectively, working in a nursery with monofilament screen.

In the monofilament screen, seedlings of substrates with higher proportion of stems show higher aboveground part and total dry phytomass than those of pure vermiculite. In the aluminized screen, the seedlings of substrate $50 \% \mathrm{RM}+50 \%$ VE showed higher phytomass and Dickson quality index (Table 2). The average proportion of these materials provided good porosity to the substrate, mainly because of the low density stems and the particle sizes, which promoted root growth and development, culminating in plants with higher phytomass, according to Costa et al. (2011) in eggplant seedlings.

Despite the fact that environments did not show differences with respect to IQD for seedlings of various substrates, as well as seedlings of substrates in monofilament screen; the seedlings, in the substrate $50 \% \mathrm{RM}+50 \% \mathrm{VE}$ in aluminized screen, obtained IQD value (0.017) similar to the ones of substrate with $100 \% \mathrm{RM}+0 \% \mathrm{VE}$ and superior to the ones of other substrates (Table 2 ). This showed that the interaction of cassava stems with vermiculite provided good balance in the distribution of plant phytomass, promoting, this way, a better quality seedling production.

In the environment with aluminized screen, the substrates with higher percentage of vermiculite did not provide higher phytomass to the seedlings. The mixture of this material with triturated cassava stems, in equal proportions, presented higher seedling quality, according to Liz \& Carrijo (2008) who comment that the mixture of two or more components, in the formulation of the substrate, promotes better physical properties for the seedling development. Other authors report better results for vermiculite when mixed to other materials. Santos et al. (2010), as an example, verified that the mixture of up to $25 \%$ vermiculite with vermicompost improves the sweet pepper seedling production.

Fruit production - For plants obtained from seedlings produced in "monofilament screen and 25\% cassava stems $+75 \%$ vermiculite" and in "aluminized screen and $0 \%$ stems and $100 \%$ vermiculite", a tendency of early production was observed, as well as the fruit number in the first 15 to 45 days of harvest. However, 
in cumulative production in 90 days no difference was observed (Table 3). The two substrates, independent of the source environment, had high amount of vermiculite, which showed high water absorption capacity and improved the initial conditions on the development of okra under field conditions, providing early fruit production. It also occurred for lettuce and sweet pepper seedlings in different proportions of substrates (Oliveira et al., 2008), using, in the composition of these substrates, coconut powder, organic compost from CEASA and vermiculite used isolated or in volumetric compositions; they observed that vermiculite and coconut powder used purely were the best substrates for seedling production.

The seedlings from substrate with $100 \%$ stems, independent of the source environment, showed delay in the formation of fruit up to 30 days of harvest. However, for total production no differences were observed (Table 3). Costa et al. (2011), working with triturated cassava stems and vermiculite, in the formation of eggplant seedlings, verified a better production with the mixture ranging from 40 to $60 \%$. The same authors report that it is possible to burn the stems or compost them, decreasing $\mathrm{C} / \mathrm{N}$ ratio, and obtaining seedlings of high quality with pure material. The seedlings of high quality provided better production under field conditions, according to Modolo et al. (2001) with okra fruit production from seedlings of different substrates composed of different varieties of commercial mixture called GII, composed of composted pine bark, rice hulls, coarse vermiculite number twelve, dolomitic limestone and fertilization with the formulas 4-14-8, FTE-BR9 and three types of trays differing in height and volume of the cells. Higher production was observed in the substrate which was added rice hulls in the proportion 1:1 to the commercial product GII regardless of the type of the tray used.

Evaluating the environmental origin of the seedlings (Table 3 ), only for the average proportion $(50 \% \mathrm{RM}+50 \% \mathrm{VE})$, the seedlings from the aluminized screen showed greater number, production and okra fruit yield than the seedlings from the monofilament screen. As verified by Costa et al. (2011), in eggplant seedling production, moderate proportions of 40 to $60 \%$ of mixture of triturated stems and vermiculite produced the most vigorous seedlings, in agreement with the results of this work.

The higher yield of okra plants, from seedlings produced in the substrate $50 \% \mathrm{RM}$ and $50 \% \mathrm{VE}$ and in the aluminized screen may be related to a better adaptation of the seedling in this environment, which provided favorable conditions for the development of the plant, adding vigor and higher field production. However, the yield was lower than the one observed by Sediyama et al. (2009), for the same cultivar. Researches in protected environments are important to improve the crop management inside them and determine the climate changes that influence plant growth caused by the use of plastic cover (Heldwein et al., 2010). The environment with aluminized screen provides a greater amount of diffuse radiation to plants, because of the material itself. The aluminized screens reflect part of the incident radiation and prevent the passage of certain fraction of infrared heat energy that warm the interior of the environment and can impair the root development and consequently the absorption of nutrients (Hora, 2003).

The proportions of $75 \% \mathrm{RM}+25 \% \mathrm{VE}$, $50 \% \mathrm{RM}+50 \% \mathrm{VE}$ and $25 \% \mathrm{RM}+75 \% \mathrm{VE}$ of stems and vermiculite, respectively, can be recommended for okra seedling production. In the substrates with higher percentage of vermiculite, the production was earlier, whereas in the substrates with only stems, the production tends to be later. The average proportions of vermiculite and stems used, for seedlings produced in the aluminized screen, provided greater number of fruits, production and yield of okra in Aquidauana-MS.

\section{ACKNOWLEDGEMENTS}

The author Cleiton GS Benett thanks to the FAPEG/CNPq for a scholarship.

\section{REFERENCES}

BANZATTO DA; KRONKA SN. 2006. Experimentação agrícola. 3. ed. Jaboticabal: Funep. 237 p.

CASTRO MM; GODOY AR; CARDOSO AII. 2004. Qualidade de sementes de quiabo em função da idade e do armazenamento dos frutos. In: CONGRESSO BRASILEIRO DE OLERICULTURA, 44., 2004, Campo Grande. Horticultura Brasileira 22: 418, Suplemento 1.

COSTA E; DURANTE LGY; NAGEL PL; FERREIRA CR; SANTOS A. 2011. Qualidade de mudas de berinjela submetida a diferentes métodos de produção. Revista Ciência Agronômica 42: 1017-1025.

COSTAE; LEAL PAM; GOMES VA; MACHADO D; JARA MCS. 2010. Biomassa de mudas de pepinos híbridos conduzidos sob ambientes protegidos. Bragantia 69: 381-386.

CRUZ CAF; PAIVA HN; GUERRERO CRA. 2006. Efeito da adubação nitrogenada na produção de mudas de sete-cascas (Samanea inopinata (Harms) Ducke). Revista Árvore 30: $537-546$.

GUEDES RE; RIBEIRO, RLD; GUERRA JGM; XAVIER GR; RUMJANEK ENG. 2006. Produtividade do quiabeiro e do feijãocaupi consorciados em sistema orgânico de produção após cultivo de crotalária ou pousio. Seropédica: UFRRJ, 2006. Disponível: <http:// www.cpamn.embrapa.br/anaisconac2006/ resumos/FT03.pdf>. Acesso em: 22 mai. 2011.

GUISELINI C; SENTELHAS PC. 2004. Uso de malhas de sombreamento em ambientes protegidos. I - Efeito na temperatura e na umidade relativa do ar. Revista Brasileira de Agrometeorologia 12: 9-17.

HELDWEIN AB; STRECK NA; STURZA VS; LOOSE LH; ZANON AJ; TOEBE M; SOUZA AT; PETERS MB; KARLEC F. 2010. Plastocrono e rendimento de feijão-devagem cultivado sob ambiente protegido e no ambiente externo em semeadura tardia no outono. Ciência Rural 40: 768-773.

HORA RC. 2003. Aplicação de luz na faixa do vermelho-extremo em mudas e diferentes sistemas de condução do tomateiro cultivado em ambiente protegido. Ilha Solteira: UNESP. 2003. 56p. (Dissertação mestrado).

KÄMPF AN. 2000. Seleção de materiais para uso como substrato. In: KÄMPF AN; FERMINO MH (org). Substratos para plantas: a base da produção vegetal em recipientes. Porto Alegre: Gênesis, p. 139-145.

LIZ RS; CARRIJO OA. 2008. Substratos para produção de mudas e cultivo de hortaliças. Brasília: Embrapa Hortaliças. 83p.

LOPES MM. 2007. Teste de vigor em sementes de quiabeiro. Jaboticabal: UNESP. 79p. (Tese doutorado)

MODOLO VA; TESSARIOLI NETO J; ORTIGOZZA LER. 1999. Desenvolvimento de mudas de quiabeiro (Abelmoschus esculentus (L.) Moench) em diferentes tipos de bandeja e substrato. Scientia agrícola 56: 377-381.

MODOLO VA; TESSARIOLI NETO J; ORTIGOZZA LER. 2001. Produção de frutos 
de quiabeiro a partir de mudas produzidas em diferentes tipos de bandejas e substratos. Horticultura Brasileira 19: 39-42.

MOTA WF; FINGER FL; CECON PR; SILVA DJH; CORRÊA PC; FIRME LP; NEVES LLM. 2006. Armazenamento de frutos de quiabo embalados com filme de PVC em condição ambiente. Horticultura Brasileira 24: 255-258.

OLIVEIRA DA; FERNANDES MB; RODRIGUES JJV; OLIVEIRA RA; COSTA FGB. 2008. Produção de mudas de pimentão e alface em diferentes combinações de substrato. Revista Verde 3: 133-137.

PURQUERIO LFV; LAGO AA; PASSOS FA. 2005. Comportamento de seleções IAC de quiabo e de uma cultivar comercial quanto à qualidade da semente. Campinas: Instituto Agronômico/APTA - Centro de Horticultura.

QUEIROGA RCF; BEZERRA NETO F; NEGREIROS MZ; OLIVEIRA AP; AZEVEDO CMSB. 2001. Produção de alface em função de cultivares e tipos de tela de sombreamento nas condições de Mossoró. Horticultura Brasileira 19: 192-196.

RODRIGUES ET; LEAL PAM; COSTA E; PAULA TS; GOMES VA. 2010. Produção de mudas de tomateiro em diferentes substratos e recipientes em ambiente protegido. Horticultura Brasileira 28: 483-488.

SANTOS MR; SEDIYAMA MAN; SALGADO LT; VIDIGAL SM; REIGADO FR. 2010. Produção de mudas de pimentão em substratos à base de vermicomposto. Bioscience Journal
26: 572-578.

SANTOS FM; PINTO JEBP; ALVARENGAAA; OLIVEIRA JA; OLIVEIRA AA; OLIVEIRA LP. 2009. Produção de mudas de Aloysia gratissima (Gillies \& Hook.) Tronc. por meio da propagação sexuada e assexuada. Revista Brasileira de Plantas Medicinais 11: 130-136.

SEDIYAMA MAN; SANTOS MR; VIDIGAL SM; SALGADO LT; PEDROSA MW; JACOB LL. 2009. Produtividade e estado nutricional do quiabeiro em função da densidade populacional e do biofertilizante suíno. Bragantia 68: 913-920.

SILVEIRA EB; RODRIGUES VJLB; GOMES AMA; MARIANO RLR; MESQUITA JCP. 2002. Pó de coco como substrato para produção de mudas de tomateiro. Horticultura Brasileira 20: 211-216. 